\title{
Study on the evolution of rural land use function in developed areas of China
}

\author{
Dianhong Zhao, Shanghai Tongji Urban Planning and Design Institute Co. LTD, China \\ This work was supported by Youth program of \\ Shanghai Planning Office of Philosophy and Social Science (2016ECK002)
}

\begin{abstract}
Under the background of "zero growth" of land use, there are many researches and explorations on the stock renewal of central urban areas in traditional planning. However, in recent years, the rural-led stock land use planning has attracted more and more attention with the development of land space planning. Village area is the basic unit of rural social and economic activities in China. The rational play of land use function in village area has important theoretical and practical significance for the realization of the multi-objective of rural revitalization under ecological civilization. Department of natural resources has issued the work pilot implementation of global land comprehensive improvement notice, rural red line "no increase of the aggregate land for construction purposes, ecological protection not breakthrough", so without any increase in construction land index on the basis of further promote rural land use composite function, is to solve the rural economy development and the important direction of rural land supply contradictions. This paper firstly makes a qualitative theoretical study on the compound mechanism of land use function in villages, and then takes 4 villages in southern Jiangsu province as examples to elaborate the compound mechanism of land use function in the development process. The results show that: (1) land use function changes due to its type and land use mode, and is indirectly influenced by natural resource endowment, social and economic conditions, regional policies, etc., the compound trend of land use function in different types of villages is often different; The land use function of the four villages in the town is as follows: the production function is transformed into the production-ecological composite function, and the living function is transformed into the production-life composite function. (3) summarize the planning of the basic ideas and function of the complex process, refine the agricultural land, unused land and construction land has the implementation of the functional complex strategy.
\end{abstract}

\section{Keywords}

Compound function, Stock planning, Land use, Construction land, Agricultural land

\section{The introduction}

Since the 21st century, the continuous development of China's "agriculture, rural areas and farmers" strategy has presented a continuous process of innovation: from balanced urban and rural development to the construction of new countryside, and then to the rural revitalization in the new era. In order to achieve the transformational development and new marginal growth of China's economy, it is urgent for domestic demand to replace investment and external demand. At present, the vast rural areas are facing a shortage of infrastructure, weak industrial development and weak economic foundation. Releasing new 
drivers of agricultural and rural development will undoubtedly be the biggest domestic demand for China's future development. At the same time, the narrowing of the gap between the rich and the poor can release the potential domestic demand, invigorate the stock and release the increment, and the implementation of the rural revitalization strategy has become an inevitable trend to release the potential domestic demand.

There are few explorations on the planning of stock land in rural areas. Countryside unit planning, which is being actively explored in Shanghai, Hangzhou and other places, includes the comprehensive land improvement in the general land use planning into the renewal unit planning level, so as to realize the full coverage of urban and rural stock land renewal planning. However, with the advancement of urbanization and the continuous role of resource constraints, rural land use planning will gradually usher in transformation and reform, and stock planning will also be gradually applied. Stock planning focuses on how to discover and realize the potential value of existing assets, while most rural areas exist in stock state. How to discover village value and revitalize village potential becomes the main content of planning. Among them, the improvement of rural land use function is an important way to realize the potential exploitation of rural stock, and also an important perspective to measure the effectiveness of rural revitalization. Land use function (LUFS) refers to the products and services provided by different land use methods. This concept was first proposed by the EU sixth Framework Project "Sustainability Impact Assessment: Environmental, social and economic Effects of Multifunctional land use in Europe" in 2008. At present, the application of land use function compound in rural areas is still weak.

In reality, the rural areas in developed regions are confronted with such problems as disordered land use structure, broken landscape space, fragile environment, delayed function improvement and mixed population structure. The complexity of land use also requires the degree of refinement of research. Therefore, studying the land use function in rural areas, especially the compound function, from the micro scale is conducive to further exploring the change situation and influence mechanism of land use function under the background of stock planning, and providing scientific basis and policy Suggestions for implementing the rural revitalization strategy.

Suzhou is one of the important central cities in the Yangtze River Delta, and its land development intensity in the "post-industrialization period" is high. At present, suzhou is close to the limit of livable city development intensity standard (30\%) in Jiangsu Province, second only to tianjin, Shanghai, Shenzhen and other mega cities. However, the construction land use and output efficiency of Suzhou town village is not high, and the layout is scattered. In 2013, Suzhou innovatively put forward the action of "three qualities, three guarantees", that is, taking the comprehensive land improvement as the starting point, on the premise of controlling the total amount of rural construction land and not occupying permanent basic farmland, it should strengthen the efforts to make use of the existing construction land, support the development of rural industries, and guarantee the land for agricultural and rural development. The Implementation Plan of Kunshan's Rural Revitalization Strategy (2018-2022) refers to the related issues of rural land composite utilization from promoting the integrated development of industries to promoting the rational allocation of land elements, so as to ensure the implementation of the city's rural revitalization goals. 


\section{Theoretical analysis: multi-functional compound mechanism of village land use}

\subsection{The influence mechanism of village land use function change}

Externally, the function of rural land use is to meet the external needs for rural regional functions, and internally, it is to meet the needs of rural development and land use subjects. Therefore, the compound function of land use in a village is influenced by both types and modes, and the types and modes of land use are influenced by the natural resource endowment, social and economic conditions, regional policies and other internal and external factors.

The town, Kunshan, is located in south Jiangsu, an economically developed area of China, and is close to the international metropolis Shanghai. Under the turbulent peng spring tide impact of urbanization, a large number of rural youth in big cities to seek a way of living, the rural "hollowing out" phenomenon is increasingly serious, this greatly "tear" and "deconstruction" traditional "village community", and because migrant workers gathered in sunan township and village enterprises in great quantities, causing the the town "reconstruction of social structure". The main body of land use in rural areas changes and USES the land use mode, which causes the change of land use function and the reconstruction of social structure. The compound phenomenon of land use function is then fed back to the regional policy and the main body demand (Figure 1).

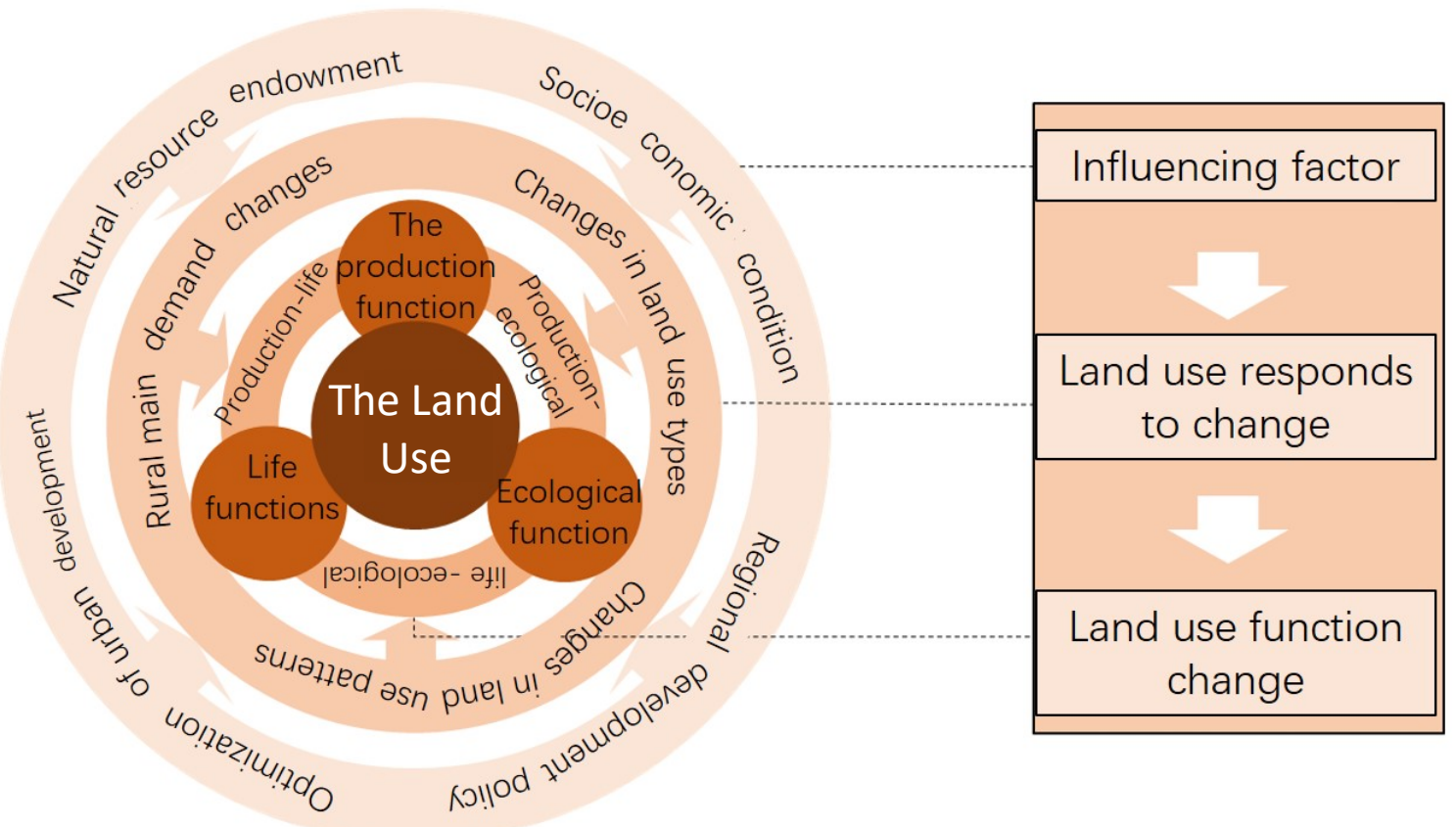

Figure 1: Influence mechanism of rural land use function change

\subsection{The multi-functional characteristics of land use in different types of villages}

Rural development has multiple goals and different development paths, and its development types also have various types. At present, the academic circle mostly divides rural development types into four types: agriculture-oriented, industrial-oriented, business-oriented and balanced development. For them by the following the change trend of rural land use function (table 1) : 1) agriculture leading the countryside, the main land use types of cultivated land, garden land, forest land, residential land and 
transportation land, grassland, etc., the main means of land use are food and vegetable planting, living, etc, the function of land use change are mainly to increase agricultural production function, life function changed, ecological function gradually. (2) industrial leading the countryside, the main land use types is arable land, rural housing land, industrial land, commercial land, park and green land, land for public service and public facilities, transportation, land use, land use type change mainly characterized by a rapid decline in agricultural land, industrial land and commercial land, land for roads, village public land, residential land phased growth, industrial land and commercial land use growth, land use function, the production function by the original agricultural production function into industrial production function is given priority to, its function to enhance the value, On the basis of the original living function, the public service and commercial service have been added. (3) business leading the countryside, the main land use types including cultivated land, forest land, rural housing land, land for tourism and land for public services and public facilities, such as land use change is mainly cultivated land decrease, the expansion of the house-site in the countryside, the tourism land, land for public services and public facilities, ecological land for a slight increase in its function of land use change, the production function by the agricultural production function into a tourism management production function, life function to increase the function of public services, and production - life of composite function, production - ecological compound function. Balanced development type may have the above types of change characteristics. With the development of rural transformation, the overall trend of land use function changes is reflected in the transformation of traditional agricultural production, rural life and ecology into modern industrial production function, multi-subject life service function and the compound function of different combinations.

Table 1: Land use functions of different rural development types

\begin{tabular}{|c|c|c|c|}
\hline $\begin{array}{l}\text { Type Of Rural } \\
\text { Development }\end{array}$ & Main Land Use Types & Land Use Subject & Land Use Function \\
\hline \multirow[t]{4}{*}{$\begin{array}{c}\text { Agricultural } \\
\text { dominant type }\end{array}$} & Arable land & $\begin{array}{c}\text { Farmers/agricultural } \\
\text { enterprises }\end{array}$ & $\begin{array}{l}\text { Agricultural } \\
\text { production }\end{array}$ \\
\hline & Productive woodland & Farmers & Production \\
\hline & Unproductive forest land & $\begin{array}{c}\text { Farmers/agricultural } \\
\text { enterprises }\end{array}$ & Ecological \\
\hline & Rural homestead & Farmers & Life \\
\hline \multirow[t]{7}{*}{$\begin{array}{l}\text { Type of industry } \\
\text { dominance }\end{array}$} & Arable land & Farmers & $\begin{array}{l}\text { Agricultural } \\
\text { production }\end{array}$ \\
\hline & Productive woodland & Farmers & Production \\
\hline & Unproductive forest land & Farmers & Ecological \\
\hline & Farmers residential & Farmers & Life \\
\hline & Industrial land & Industrial enterprise & $\begin{array}{l}\text { Industrial } \\
\text { production }\end{array}$ \\
\hline & Commercial land & Merchants & $\begin{array}{l}\text { Commercial } \\
\text { production }\end{array}$ \\
\hline & $\begin{array}{l}\text { Land for public services } \\
\text { and facilities }\end{array}$ & $\begin{array}{c}\text { Farmers/industrial } \\
\text { enterprises/merchants }\end{array}$ & Life service \\
\hline
\end{tabular}




\begin{tabular}{|l|c|c|c|}
\hline $\begin{array}{c}\text { Business travel } \\
\text { service }\end{array}$ & Arable land - Farmland & Farmers & $\begin{array}{c}\text { Agricultural } \\
\text { production }\end{array}$ \\
\cline { 2 - 4 } & $\begin{array}{c}\text { Cultivated land - } \\
\text { Landscape }\end{array}$ & tourists & $\begin{array}{c}\text { Tourism production } \\
\text { - Ecology }\end{array}$ \\
\cline { 2 - 4 } & Productive woodland & Froduction \\
\cline { 2 - 4 } & $\begin{array}{c}\text { Unproductive woodland - } \\
\text { Landscape }\end{array}$ & Production-Life \\
\cline { 2 - 4 } & \begin{tabular}{c} 
Rural homesteads - living \\
\cline { 2 - 4 }
\end{tabular} & Fural homesteads - \\
Commercial use & Formers & Production-Life \\
\cline { 2 - 4 } & $\begin{array}{c}\text { Land for public services } \\
\text { and facilities }\end{array}$ & Farmers/tourists/merchants & Life \\
\hline
\end{tabular}

\section{Case Study: The compound strategy of land use characteristics and functions in rural areas in China's first development region}

\subsection{Study area and data source}

The town belongs to Kunshan City of Jiangsu Province, with Dianshan Lake in the east, Chenghu Lake in the west, Qingpu District of Shanghai in the south and Wuzhong District of Suzhou and Zhangpu Town of Kunshan in the north. The town covers a total area of $90.69 \mathrm{~km} 2$. The town has jurisdiction over 3 communities and 20 administrative villages. Jinxi has a permanent population of 660,000, including 430,000 registered residents. Jinxi is a land of fish and rice, with a wetland area of $42.4 \mathrm{~km} 2$, equivalent to $46.8 \%$ of the total area of the town. There are five lakes, Chenghu lake, Qianwan Lake, Yangshudian Lake, White Lotus Lake, Changbai Lake, Mingjing Lake and Ruanbai Lake. Jinxi, with a history of more than 2,500 years, is a famous ancient kiln town with zhudian ancient kiln site group, Chenfei Water tomb and other cultural preservation units. It is also the hometown of art. Jinxi is the township with the most intangible cultural heritage projects in Kunshan, including Jinxi Propaganda scroll and Jinxi Brics. It has long been known as the hometown of Folk museums in China.

On June 22, 2018, The town government signed a strategic cooperation agreement with Tongji University's School of Architecture and Urban Planning for rural Revitalization, and Shanghai Tongji Urban Planning and Design Institute undertook the research work of the town's rural revitalization strategy. Overview of the study area and influence factors analysis of data and information derived from the kunshan city government work report on industry development, tourism policy document report, the town planning and construction, as well as the population, employment and basic statistical data and field survey of the construction of the village, and WeChat questionnaire survey data .

3.2The diversity of land use nature and the complexity of land ownership

The town land property includes agricultural land, construction land and unused land. Taking the four pilot projects as an example, the total proportion of cultivated land is the highest, because since the implementation of the "four million mu" project in Suzhou, the cultivated land area of The town has increased from 17,000 mu to 23,000 mu. Construction land in the main land properties for the rural residential land and industrial and mining land for storage, inventory planning will land and industrial land as the main object of land management, land use, multiple function diversification and 
characteristics of land use pattern and function change of the region, summarizes the village domain way of sustainable land use, and can provide a reference for similar country .

The town land ownership covers state-owned land and collective land. State-owned land distribution is less, the factory enterprises and office buildings obtained by means of transfer, such as Xiagang village, Zhubang village, etc. The collective land accounts for a large proportion, and the agricultural land, homestead and profit-oriented construction land in rural areas mostly belong to the collective land. Compared with the state-owned land property right system, the rural collective land property right system is not perfect, and the collective land transfer is not complete legally. In the practice of market economy in The town, villagers have a stronger and stronger awareness of the collective land transfer, the realization of power and power, and the protection of farmers' rights and interests, such as Zhubang Village (figure 4).

\subsection{Land use function classification and spatial difference analysis in The town}

In combination with the remote sensing interpretation of ArcGIS and the standard of "Guidelines for Zoning and Use Classification of Municipal and County Land Space Planning (Trial, draft submission)", the town's land use functions are divided into 6 major types (Table 2, Figure 6-12). The six land use function types can be divided into two categories: one is the traditional land use function type, which can be divided into three basic land use functions: production function, living function and ecological function; The other type is the compound land use function type, including production-life compound function, production-ecology compound function, production-life-ecology compound function.

Table 2: Land space use classification table of each village in The town (classified according to land use function)

\begin{tabular}{|l|l|}
\hline Land Use Function & \multicolumn{1}{|c|}{ The Town Land Space Planning Use Classification } \\
\hline $\begin{array}{l}\text { The production } \\
\text { function }\end{array}$ & $\begin{array}{l}\text { Paddy field, irrigated land, pit surface, class I homestead, land for rural } \\
\text { production and service facilities, land for rural tourism and reception, land for } \\
\text { social parking lots, land for village roads, rural roads, etc }\end{array}$ \\
\hline $\begin{array}{l}\text { Ecological } \\
\text { function }\end{array}$ & $\begin{array}{l}\text { Arbor woodlands, other woodlands, natural reserves, river surface, pit surface, } \\
\text { land for rural settlements, land for village roads, rural roads, etc }\end{array}$ \\
\hline $\begin{array}{l}\text { Life functions } \\
\text { recombination } \\
\text { (Narakang Village) }\end{array}$ & $\begin{array}{l}\text { Class I or Class II homestead, land for rural community service facilities, pit } \\
\text { surface, land for village roads, rural roads, etc } \\
\text { surface of rivers, pits, lakes, land for village roads, rural roads, etc }\end{array}$ \\
\hline $\begin{array}{l}\text { Life-production } \\
\text { Compound } \\
\text { (Changyun } \\
\text { Village) }\end{array}$ & $\begin{array}{l}\text { Land for class I or Class II homesteads, land for rural production and service } \\
\text { facilities, land for rural tourism and reception, land for social parking, paddy } \\
\text { fields, irrigated land, river surface, pit surface, land for village roads, rural roads, } \\
\text { etc }\end{array}$ \\
\hline $\begin{array}{l}\text { Production-life- } \\
\text { ecology } \\
\text { compound (Jiadun } \\
\text { Village, Zhubang } \\
\text { Village) }\end{array}$ & $\begin{array}{l}\text { Class I or Class II homestead, land for rural production and service facilities, land } \\
\text { for rural tourism and reception, land for social parking, park green space, paddy } \\
\text { village road surface, rural road, etc }\end{array}$ \\
\hline
\end{tabular}


Note: In Table 7, the purpose of territorial space planning within the administrative boundaries of The town is classified. The classification method is oriented to specific regions (The town), and different regions should adjust, increase or decrease according to local conditions.

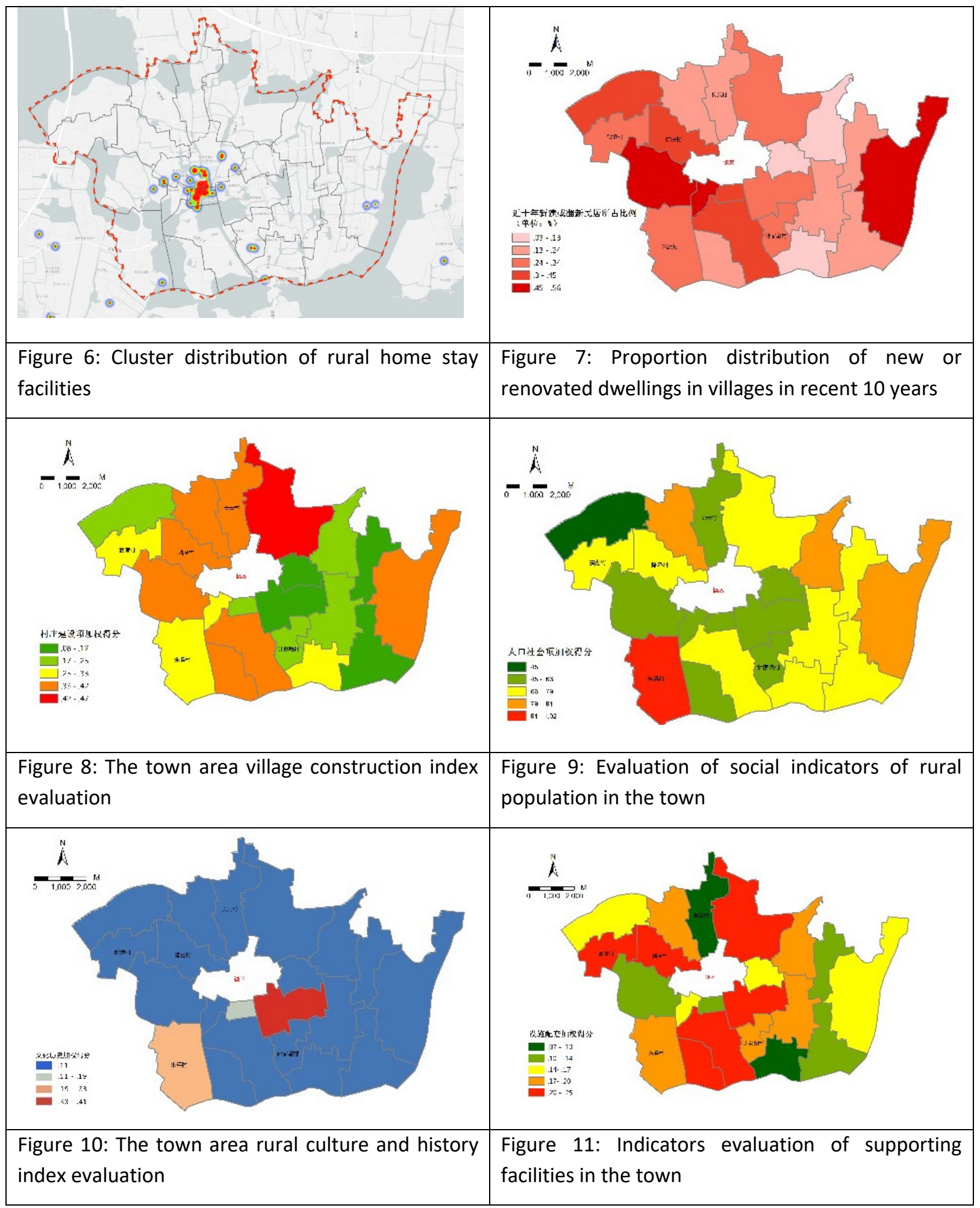


Zhao, D.

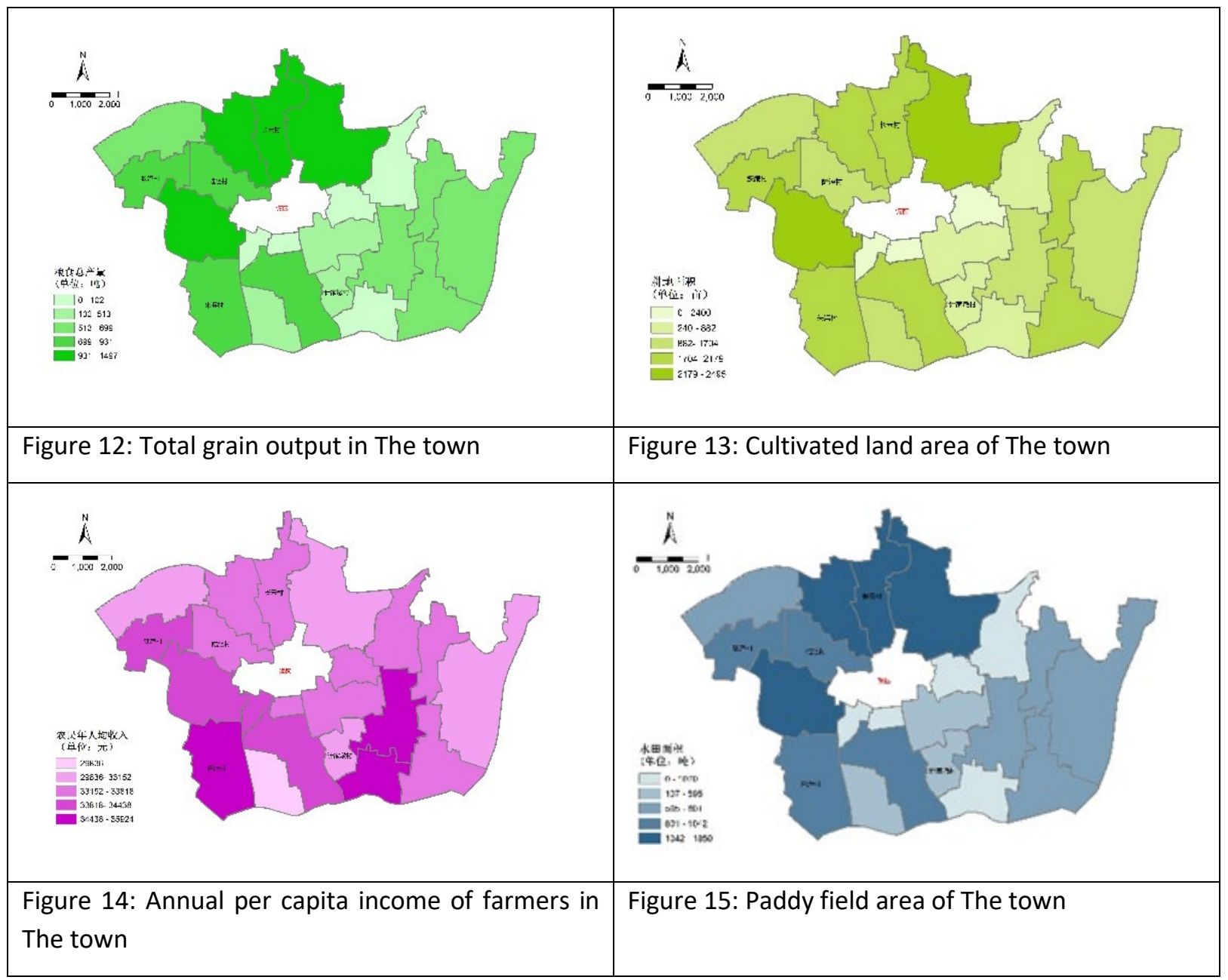

By comparing the land use function pattern of The town in 2010 and 2018, the agricultural production function of The town has been transformed into the production-ecology compound function that focuses on rural tourism development and agricultural production, and the living function mainly assumed by homestead has been partially transformed into the production-life function. Function of land use efficiency gains and the characteristics of the composite function, single production, ecological function were decreased, the most evolved into composite features, production - production - life ecological compound function, space and by a single type of each function features mainly scattered into different functional types of concentrated distribution (figure 16).

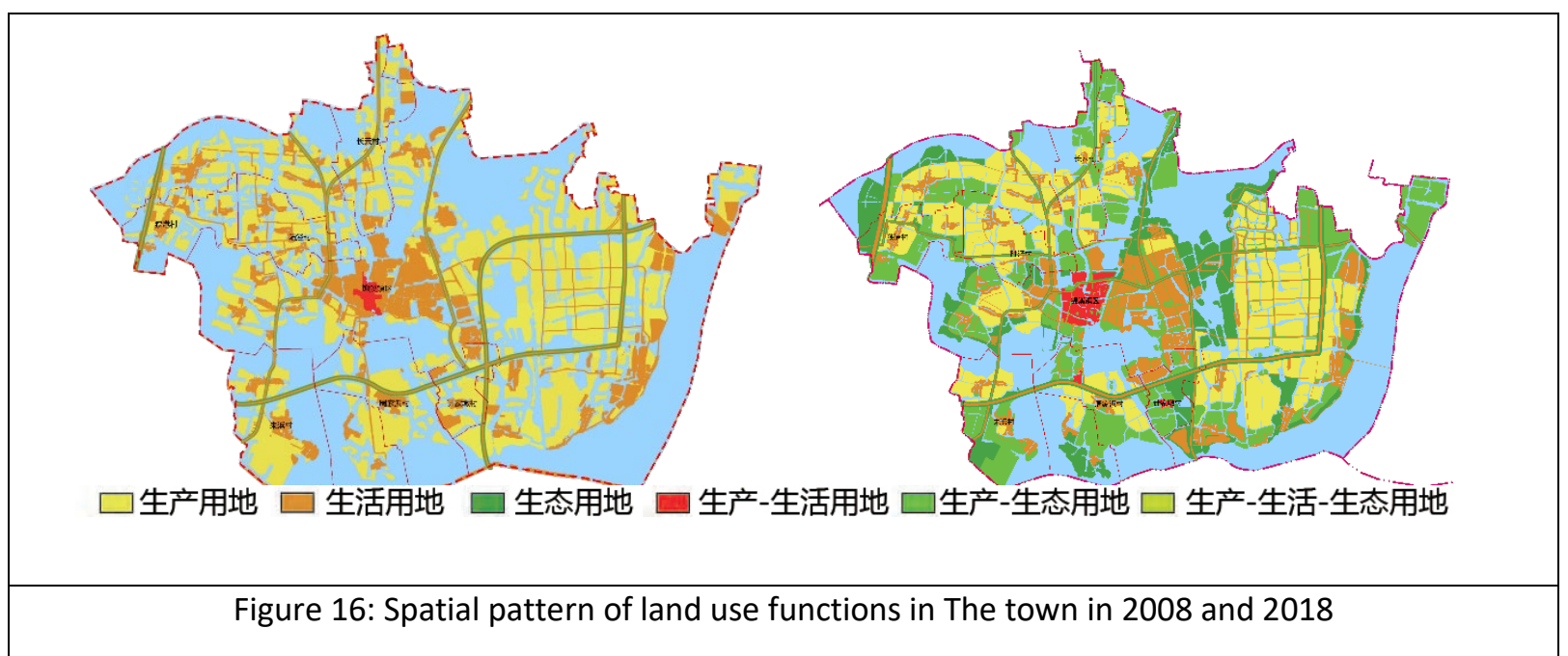




\subsection{Land use function compound strategy of The town}

\subsubsection{A functional compound strategy for agricultural land, water and unused land}

Strategy 1: Changyun Village model -- strictly protect the basic farmland and enhance the functional value of agricultural land

Under the national cultivated land protection policy, the nature of cultivated land is not significantly adjusted because suzhou takes the rigid protection principle of basic farmland as a control strategy to control the urban growth boundary and construct the urban green barrier. The policy of "three rights division" (ownership rights, contract rights and management rights) has also provided conditions for large-scale agricultural operations, helping to adjust scattered farmland to focus on contiguous areas. Changyun village for collective management, take the road of large-scale development. The contracted farmland will be returned to farmland by village collectives, reclaimed and ploughed, and more than 1,900 mu of high-standard farmland will be built. At the same time, resources should be integrated and standardized production modes implemented. Farmland share cooperatives should coordinate and allocate capital, technology, labor force, land and other factors of rural production, so as to realize centralized support for agricultural technology services, carry out centralized management of agricultural production and implement standardized production modes. On this basis, the functional value of agricultural land is further enhanced, and agricultural land composite utilization is carried out by means of agricultural tourism development (FIG. 16).

Strategy 2: The Model of Xiagang Village -improve the ecological conservation function of water area and garden, and excavate the functional value of ecological land

The ecological damage of Xiagang village is quite serious, such as the broken town caused by road

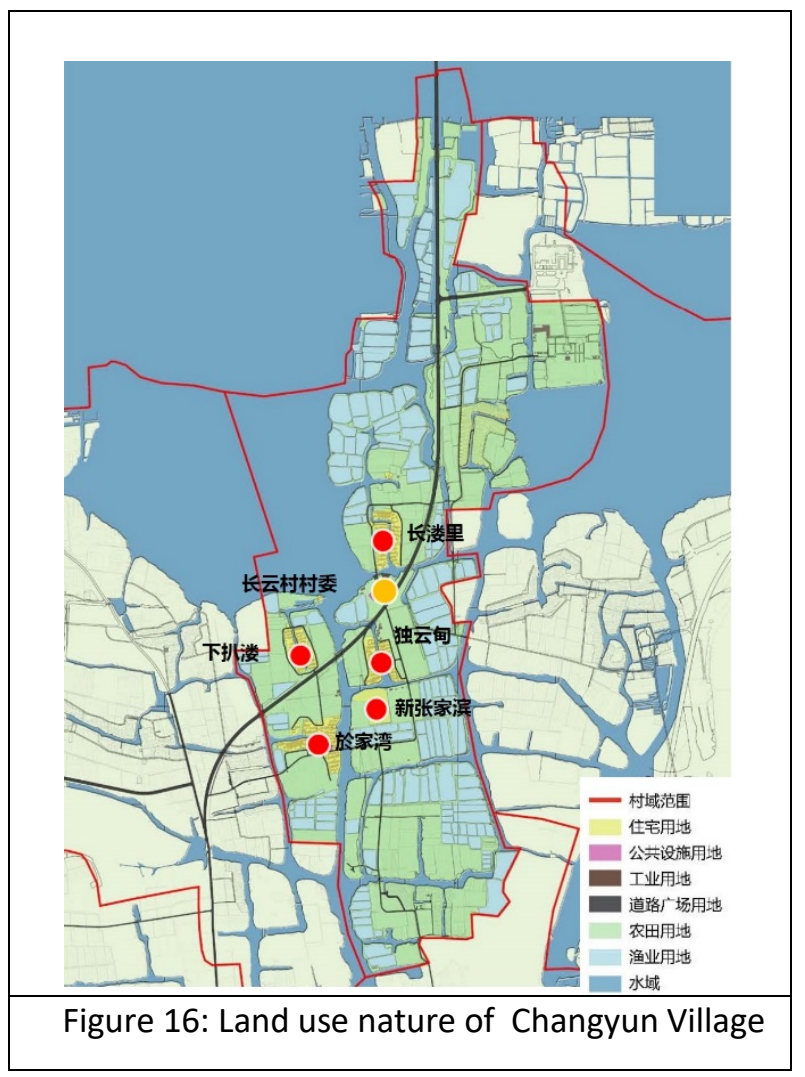
construction, ecological pollution caused by excessive fishery breeding, and the brownfield abandoned after industry withdrawal. The water area has an important ecological conservation function and is also the natural habitat for a variety of organisms. The ecological restoration and conservation project of the beechebang should be carried out in accordance with relevant norms such as the Surface Water Environmental Quality Standard (GB3838-2002) and GB 11607-89 Fishery Water Quality Standard. In the restored garden, green industries such as recreation, health preservation and ecological education are carried out according to the current development of each unit, so as to realize the production-ecology complex function (Figure 17-18). 


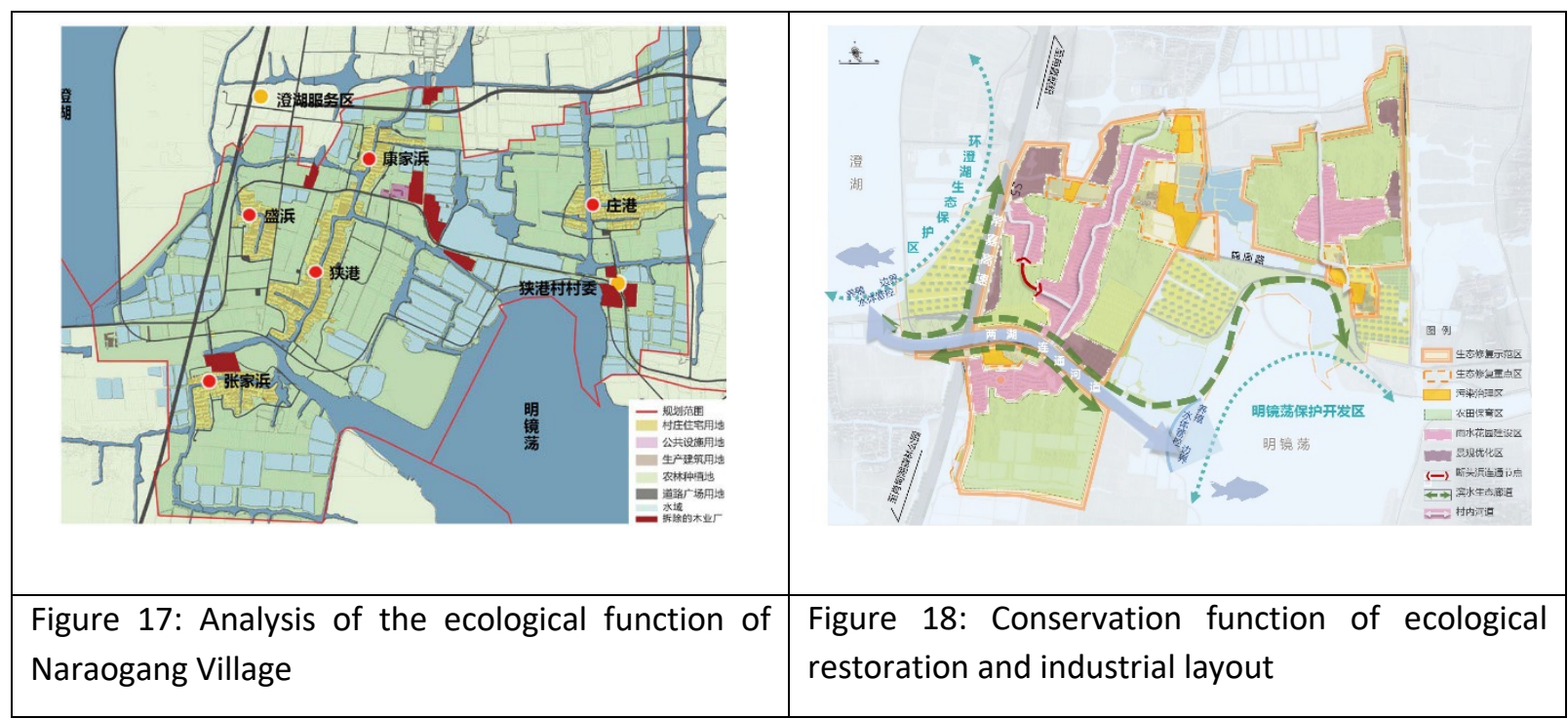

\subsubsection{Functional compound strategy of construction land}

Strategy 3: Jiadun model -- to sort out scattered homestead and improve its functional value and environmental quality.

Jiadun village due to the serious hollowing phenomenon, homestead use efficiency is low. 2015 jinxi government plan comprehensive consolidation settlement of land resources, use of idle land functional replacement promulgated by the state policy, the rural collective land circulation, and persuade some villagers transfer from construction management of 20 years, with township resettlement compensation in the form of the final sign the leasing agreement which is done by the market subject, for the overall planning and design, project investment and investment construction, operation and management. It is planned to introduce diversified characteristic cultural and travel formats such as home stay in the ideal village mode. By combining the rural living environment with the layout of characteristic formats, the hardware updating of the construction level can be realized. At the same time, "public funding" and other ways to promote the new era of urban talent "to the countryside", the realization of community level software construction (figure 19-20).
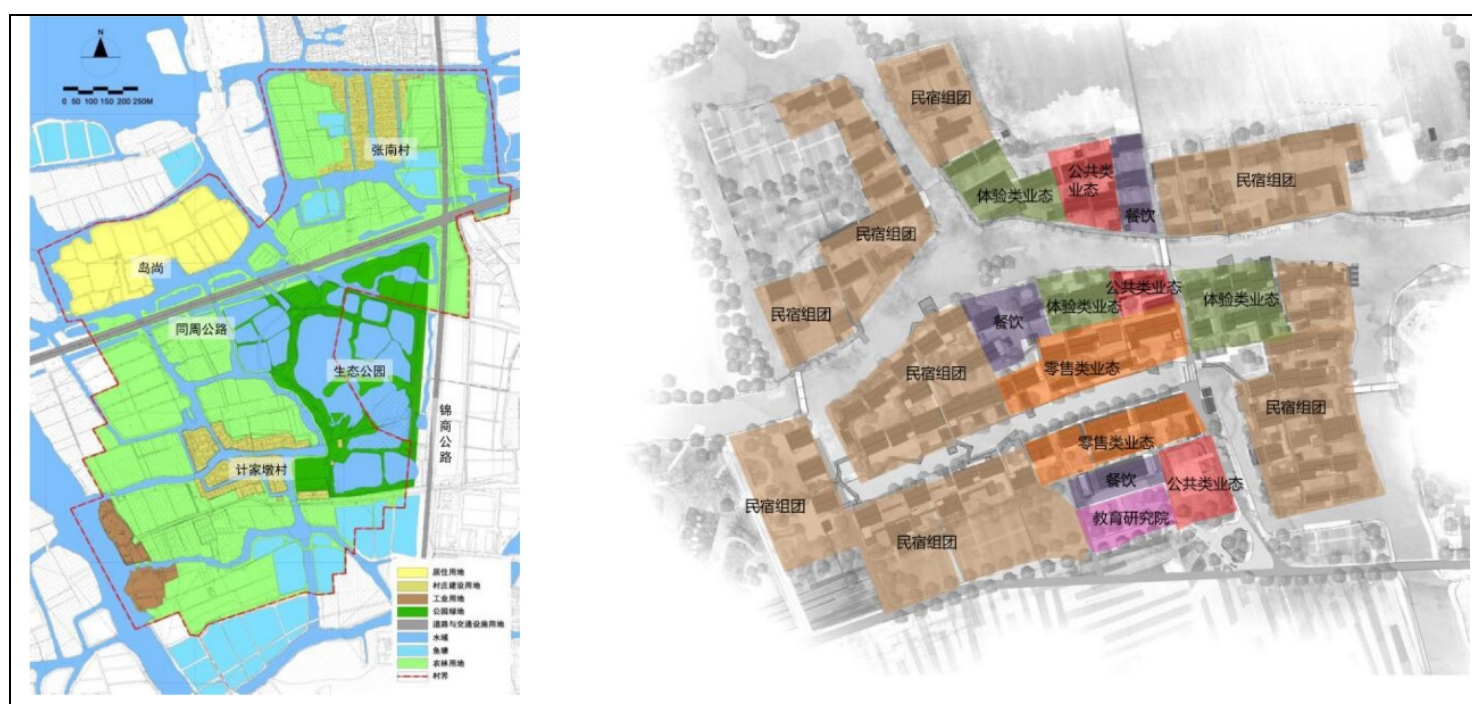

Figure 19: Schematic diagram of land $\quad$ Figure 20: Function composite layout of Jiadun Natural Village 
use in Jiadun Administrative Village

In the process of transforming the functions of homestead, the nature of land use and land ownership remain unchanged, and the homestead shall be operated after the relevant departments issue business licenses and other certificates. According to local market demand, on the basis of the original function of living increase production function, the development of the third industry, not only improved the living environment surrounding the house-site in the countryside, attracting city people consumption at the same time, for the indigenous people also offers participation in rural tourism development and management of the new formats and the possibility of extending the rural tourism industry chain, let colorful rural scene. Jiadun Village has successfully held a large scale and influential exhibition (including activities such as countryside Partner · Art Season, Tian Shang Life Festival, etc.), which has become an ideal rural living cluster between Shanghai and Suzhou.

\section{Strategy 4: Zhubang Village model -- reduce the amount of land for industrial construction, and serve the construction of agricultural science and innovation and cultural tourism.}

Most of the factories in zhubincun are manufacturing plants such as printing, paper and shoe heel factories, which provide jobs for local and migrant workers but also face environmental pollution and high regulatory costs. In suzhou to promote the "four million mu" project, the nature of industrial land in Zhubang Village industrial park was adjusted to agricultural land, which had a huge conflict with the vested interests of the original business owners. (If the enterprise needs to be closed, relocated or transformed, both the owner and the employee need to face higher costs and risks), the phenomenon of petition is frequent. At the request of The town government, the planning intervenes as a third party. The purpose is to help the village enterprises to gradually convert the land for industrial use, and finally to transform the land at the lowest cost and risk. On the basis of extensive consultation with business owners and villagers, the planning initially evaluates the building quality of the industrial workshop, and determines the demolition, reconstruction, retention and renewal of the building. After the planning, the floor area of the building will be reduced by $52 \%$, the total floor area by $30 \%$, and some factories will be renovated and replaced (See Figure 21-22).
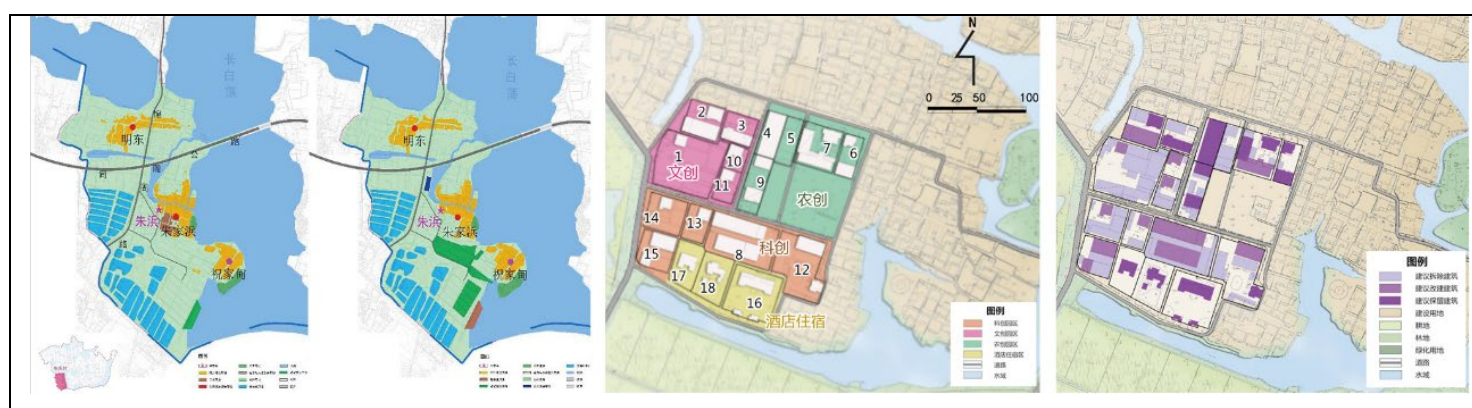

Note: This solution is only a short-term transition solution to reasonably resolve the conflict

Figure 21: Land use diagram of Figure 22: Functional composite layout of Zhubang Natural Village Zhubang Village

Plan to improve the ecological and living environment quality, and transform the workshop space to form the industrial site cluster; The cultural and creative area displays the development of Jinxi industry; the agricultural innovation area carries out ecological agriculture experience activities; the science and innovation area builds the science and innovation office complex; the hotel area provides leisure, living, health and other facilities. Strengthen ZhuDian kiln near base and cultural center, jiangsu provincial cultural relics protection units, and with catering, leisure, vacation, conference, exhibition and other 
functions) spatial linkage effect, formation of art of culture, farming culture and industrial culture, ancient kiln four state unity of new rural community network core, creating multiple dynamic and continuous dynamic.

\section{Discuss}

In this paper, the land use function compound in rural areas under the background of stock planning is studied only in the first development area of China. Given the variety of rural development, it is necessary to further comparative study of different types of rural land use function composite and security policy research, to deepen to the transformation of rural development, nakamura domain composite understanding land use function, for the sustainable development of land use scientific and reasonable policy Suggestions and measures are put forward.From the method, based on high resolution remote sensing data to land basic feasible practical use characterization methods such as land use function, but given the difference in the degree of use of the same type of land use type, land use activities can also be included in the input and output in the future situation of investigation and study, strive to distinguish between dominant and recessive characteristics of land use composite ensure the accuracy of land use function to judge.

\section{Reference}

1. Liu Yansui.(2008). Urban-rural Integration and Rural Revitalization in The New Era of China. Journal of Geography, 2008,73 (10): 1837-1849.

2. Zhao Yanjing.(2014).Inventory planning: Theory and practice. Planning and construction in Beijing, 2014 (4): 153-156.

3. Zhen Lin, CAO Shu-yan, WEI Yun-jie, XIE Gao-di, LI Fen, Yang Li.(2009). Multifunctional Utilization of Land space: Theoretical Framework and Empirical Study. Resources science, 2009,31 (4) : 544-551.

4. Perez-Soba M, Petit S, Jones L, et al.(2008).Land use functions: A multifunctionality approach to assess the impact of land use changes on land use sustainability. In: Katharina H, Marta P, Paul T. Sustainability Impact Assessment of Land Use Changes. Heidelberg: Springer-Verlag Berlin Hei delberg, 2008: 375-404.

5. Liu Chao, XU Yue-qing, SUN Pi-ling, LIU Jia.(2016).Research progress and Prospect of land use versatility. Progress in geographical sciences, 2016,35 (9) : 1087-1099.

6. Ren Guoping, LIU Liming, SUN Jin, et al.(2018).Multi-functional positioning of urban Suburban rural Landscape based on GRA and TOPSIS models. Geography Research, 2018, 37(2): 263-280.

7. Zhou Ling.(2017).An Analysis of the Spatial Evolution Mechanism and Countermeasures of Megalopolis Fringe Areas: A Case study of Shanghai. Journal of Urban Planning, 2017, (3): 85-94.

8. Zhao Tong, Ma Xiaodong, CAI Wei Yu.(2014).Differentiation and Regional Types of Rural Economic development in Jiangsu Province. Regional Research and Development, 2014, 33(2): 67-72. 